\title{
Analysis of Perceptions of Conventional and E-Learning Education in Corporate Training
}

\section{Conková Monika}

\begin{abstract}
The necessity of today concerning the need to optimize the learning process has led to the development of e-learning. Organizations gradually incorporate e-learning into their educational activities. However, blended learning, which combines online components with the conventional face-to-face components, has emerged as an alternative way of teaching and learning. The paper presents selected research results that compare the perceived attributes of e-learning and conventional business training in an organization operating in the Slovak market. The purpose of the analysis was to determine, which style of learning is preferred, subjectively more beneficial and better evaluated by employees of the company for the purpose of supporting decision-making in company's business education strategy development. Two thrifty summated scales, both of four original items rating the properties of two types of business training were compiled with acceptable reliability assessed by internal consistency coefficient and validity established by factor analysis. The results showed comparable perceived quality, effectiveness, efficiency, and knowledge applicability of two types of business training in the company, balanced preferences and thus vindication of both styles of training in business education program. Regarding practical implications, this study proposes the concept of thrifty multidimensional learners' evaluation, which can be used in organizations providing different styles of business training for quantitative evaluating and monitoring the perceived trainings' quality attributes, their benefit, effectiveness and efficiency for quick inspection of relevant differences between the two styles of training in company. Realizing the existence of deficiencies in the training can support corrective actions starting toward training's quality and effectiveness and efficiency optimization.
\end{abstract}

Keywords: e-learning, classroom education, educational process efficiency and effectiveness

JEL Classification: I21, M53

\section{INTRODUCTION}

Appropriately skilled workforce is a necessary precondition for companies' competitiveness in all advanced economies. Employers, thus, encounter a problem of ensuring adequately skilled workforce for their businesses to be/stay competitive in changing markets (Kakkar, 2008; Klimplová, 2012; Šimová, Závadský, \& Andrejkovič, 2008). One way to ensure such workforce is to provide appropriate education and training. The present time requires people learning new knowledge and skills more and more effectively and efficiently. Insistently ever increasing need for innovative ways of providing education over time leads to dramatic changes in technology and organization of teaching (Cervená, 2011). The development of computer and network technologies provides various facilities to promote the teaching way more personal, flexible, unbundled local and available on request. These radical changes in learning needs and technol- 
ogy are fueling a transition in modern learning in the era of the Internet, commonly referred to as e-learning. These radical changes in education and in its technology of provision have transformed teaching into the modern era of the Internet called e-learning (Shea, 2002 in Dongsong, Zhao, Lina, \& Nunamaker, 2004). Examination shows that the Internet with newest technology are transforming the way of providing education and e-learning becomes a viable alternative to the traditional "classroom" teaching. Currently, businesses, public organizations and educational institutions need to understand the e-learning and take a decision on the adoption of e-learning techniques in their specific business circumstances.

As the literature review demonstrates e-learning is becoming an important learning style in many countries and in many different areas of education or business training. The use of e-learning offers the learner many opportunities to control and make decisions on his own, anytime or anywhere, affording a much more flexible training schedule. For the employer, the use of e-learning can influence employees regarding training and development; it may more efficiently trains employees by cutting down on time away from the office, and it can reduce costs associated with traveling to training programs. While it appears on the surface that e-learning as a training strategy has many benefits, a number of studies have reported mixed results with elearning practices. Currently, a limited number of empirical studies exist that examine learner satisfaction among adult learners in an industry setting taking e-learning courses. Consequently, guidance to industry leaders and practitioners who wish to employ e-learning for training purposes is also limited. (Hairston, 2007). Similarly, while information systems success models have received much attention among researchers, little research has been conducted to assess the success and/or efectiveness of e-learning systems in an organizational context (Y.-S. Wang, Wang, \& Shee, 2007).

The aim of this article is therefore to contribute to the research evidence of business training e-learning system analysis with focusing on comparing the perceived quality, effectiveness and efficiency of e-learning and traditional way of training employees in a particular company.

\section{THEORETICAL BACKGROUND}

Nowadays, as we are experiencing a magnificent and rapid change in technology and science, the central role of human capital theory lies in the increasing importance of knowledge acquired through cognitive processes more or less complex and assumed in the production system (Bucciarelli, Muratore, \& Odoardi, 2010). The economic growth and competitive positioning depend, in a gradually increasing, on the quantity and quality of learning achieved, becoming the essential means by which companies acquire and manage knowledge, new source of advantage for the socio-economic system (Wild, Griggs, \& Downing, 2002). Globalization and technology are altering our views on education and educational offerings. Technology has given birth to many new avenues for learning. Among the reforms in course delivery, e-Learning system (online learning) enjoys a predominant position (Mouzakitis, 2009). Corporate e-learning market is witnessing a rapid growth particularly over the last decade (Bucciarelli et al., 2010). A large proportion of organizations are adopting e-learning as their preferred method for human resources skills development (Mansour, 2009). E-learning is starting to become main stream in the educa- 
tion and training systems (Mihartescu, Negrut, \& Mazilescu, 2010). It is beneficial on two key counts: 1 . It meets the current demand to rapidly create learning resources to address business events, competitive developments, product trainings or other business needs. 2. It helps minimize the time and resource contribution from the student. E-learning was intended to be the future of learning that focuses on both the individual requirements of learners and the content delivered (Clark \& Mayer, 2008) in (Al-Furaydi, 2013).

E-learning has been variously defined, depending on the needs of particular organizations and circumstances. The evolving definition of e-learning describe e-learning as the instructional content or learning experiences delivered or enabled by internet technology to enhance an individual's knowledge and performance. This definition is derived from the Commission on Technology and Adult Learning by the American Society for Training and Development and National Governors Association, US (Pantazis, 2001). For our purposes, a simple definition will suffice: "E-learning or technology enhanced learning describes the use of technology to support and enhance learning practice” (Mayes \& De Freitas, 2006 in Vargas \& Tian, 2013).

Efficient and effective training methods are always the key for companies ensuring that their staff and partners have the latest information and instructions. Harrying to meet this need, universities and commercial entities around the world offer thousands of online courses, including certification and higher education programs. For example, in 2001 the Massachusetts Institute of Technology promised to freely publish all their training materials for non-commercial use. A year later, nearly 50,000 students, about $70 \%$ more as in the previous academic year enrolled the first and second stages of higher education at on-line University of Phoenix-e (Shea, 2002). A 2010 study reports that, as of 2009 in the US, online enrolments have continued to grow at rates far in excess of the total higher education student population, with the most recent data demonstrating no signs of slowing (Allen \& Seaman, 2008; Vargas \& Tian, 2013). Internet has become the dominant means of delivering information and education because of low operating costs and real time delivery. Compared with traditional teaching in classrooms with teachers, in which the learning process focuses on the instructor who has control over the class, its composition and the course, e-learning offers a focus on student learning at their own pace (Hiltz \& Turoff, 2002). Tab. 1 shows the advantages and disadvantages of e-learning compared to traditional teaching in classrooms. 
Tab. 1 - Advantages and disadvantages of e-learning compared to traditional learning in classroom. Source: Dongsong, Zhao, Lina, \& Nunamaker, 2004.

\begin{tabular}{|c|c|c|}
\hline & $\begin{array}{c}\text { Traditional Classroom } \\
\text { learning }\end{array}$ & E-learning \\
\hline Advantages & $\begin{array}{l}\text { - Immediate feedback } \\
\text { - Being familiar to both } \\
\text { - instructors and students } \\
\text { - Motivating students } \\
\text { - Cultivation of a social } \\
\text { community }\end{array}$ & $\begin{array}{l}\text { - Learner-centered and self-paced } \\
\text { - Time and location flexibility } \\
\text { - Cost-effective for learners } \\
\text { - Potentially available to global audi- } \\
\text { ence } \\
\text { - Unlimited Access to knowledge } \\
\text { - Archival capability for knowledge } \\
\text { reuse and sharing }\end{array}$ \\
\hline Disadvantages & $\begin{array}{l}\text { - Instructor-centered } \\
\text { - Time and location con- } \\
\text { straints } \\
\text { - More expensive to deliver }\end{array}$ & $\begin{array}{l}\text { - Lack of immediate feedback in asyn- } \\
\text { chronous e-learning } \\
\text { - Increased preparation time for the } \\
\text { instructor } \\
\text { - Not comfortable to some people } \\
\text { - Potentially more frustration, } \\
\text { - anxiety, and confusion }\end{array}$ \\
\hline
\end{tabular}

Except of the positives, e-learning meets also some undesirable features. Underequipped e-learning systems can lead to frustration, confusion and reduced interest of participants (Maki, Maki, Patterson, \& Whittaker, 2000). Some e-learning systems are presented as text only educational materials, which can lead to bored and uninterested students and prevent them to understand the subject. With the development of multimedia technology, more is available on multimediabased e-learning systems. These systems integrate and present educational materials in various media such as text, image, audio and video. Some multimedia system is failing due to a lack of interactivity and flexibility because of passive and unstructured way of presentation of instructional content. In these systems, the trainees have relatively little control over the structure of knowledge and the process of obtaining them according to individual needs.

The latest information technology utilizes opportunities of technological progress and theoretical developments in e-learning. Technically, it is necessary to propose an efficient method combining multimedia contents and, in theory, it is necessary to understand the impact of various factors on e-learning effectiveness (Dongsong, Zhao, Lina, \& Nunamaker, 2004).

At present, e-learning is still in its infancy with many unsolved questions. There are many factors potentially influencing e-learning effectiveness, for example nature of media, content, technology, trainee's nature. Although some research has shown that e-learning can be at least as effective as conventional classroom learning (Batte, Forster, \& Larson, 2003; Blake, Jane Whitney, \& Blackwell, 2003) in a particular situation, it cannot be proved that e-learning can replace 
traditional classroom learning. Learning is largely a socio-cognitive activity and not every person mainly who is in generally frustrated of computers adopts e-learning as a suitable learning style. Some trainees said that although e-learning educational system is an interesting and effective, if given the choice, they would still prefer the traditional system of teaching with the teacher in the classroom. E-learning requires more maturity and self-discipline from students than in the case of classical education, which may explain the higher rate of students early ended study in case of e-learning form of learning (Hiltz \& Wellman, 1997).

There are also logistical problems of e-learning. Learning on the Internet for example, requires more of teacher's time to prepare the lesson than it is needed in case of traditional teaching. Certain types of learning materials are too difficult or expensive to be used in on-line teaching. Also other important issues of e-learning must be taken into an account such as a matter of trust, authorization, confidentiality and individual responsibilities, the owners of intellectual values should be suitably compensated. Internet security is a growing challenge primarily because of public access to the global network. Finally, since multimedia materials in e-learning systems are often used, a prerequisite for efficient access to the content network with broadband.

E-learning covers a wide set of applications and processes, such as Web-based learning, computer-based learning, virtual classrooms, and digital collaboration. It includes the delivery of content via Internet, intranet/extranet (LAN/WAN), audio-and videotape, satellite broadcast, interactive TV, and CD-ROM. E-learning can be delivered through synchronous and asynchronous means. Synchronous e-learning models tend to follow the traditional-classroom model. Online lectures are the "driver" of the course (Midkiff \& DaSilva, 2000 in Kakkar, 2008). The asynchronous e-learning model requires students to learn independently.

Asynchronous e-learning takes place when learners can complete the course with minimal or no interaction with the course instructor (Omwenga \& Rodrigues, 2006). Asynchronous online learning can take place anywhere and anytime it is needed. Asynchronous e learning can include (a) a self-paced course, (b) exchanging email messages with an instructor, and (c) posting messages to a discussion group (Kakkar, 2008). In asynchronous e learning environments, student may be less motivated to complete the course because most often they are without any real-time human interaction (Morse, 2003). In addition, learners are not provided with immediate feedback on their performance.

Synchronous distance education is defined as "the time-and-place-dependent nature of classroom instruction proceeding in synchronization with a distance education classroom located in a remote location and connected by video conferencing, audio-conferencing media or both" (Bernard et al., 2004 in Kakkar, 2008). In asynchronous e-learning course, communication and interaction between the participating individuals occurs instantly and the participants can access the information at the same time. Some of the characteristics defining synchronous e learning include (a) audio conferencing, (b) satellite broadcasting, (c) video teleconferencing, and (d) chat rooms (Kakkar, 2008).

Education benefits of e-learning and positive perceptions of e-learning among students and trained employees have been confirmed in numerous research studies (Hussin, Bunyarit, \& Hussein, 2009; Vargas \& Tian, 2013). Although technology comprises an important element of e- 
learning, successful e-learning commands more than just technologies. Other elements, which include appropriately designed courses, relevant, current content, reliable and strategic teaching plans, and service/support from all levels staff are also considered essential. On the other side, online interaction with lecturer do not guarantee a high quality interaction compared to face-toface interaction (Hussin et al., 2009).

Many organization and researchers have started to measure success of e-learning programs using various metrics from learners' satisfaction (Al-Furaydi, 2013; Bhattacherjee, 2001; Luor, Hu, \& Lu, 2009; Mansour, 2009; Ozturan \& Kutlu, 2010) to e learning's efficiency and positive impact on customer service, productivity and sales (Berry, 2000; Ho \& Dzeng, 2010; Nakayama, da Silva Schroeder, Pilla, Haro, \& Binotto, 2005; Olafsen \& Cetindamar, 2005; Pilla, Nakayama, \& Nicholson, 2006; Yeung \& Jordan, 2006) or have compared most often with no significant difference using a traditional lecture-based approach, and the other studying using e-learning (Ho \& Dzeng, 2010; Lim, 2002; Russell, 1999; Schoenfeld-Tacher, McConnell, \& Graham, 2001; Suanpang, Petocz, \& Kalceff, 2004) or have analyzed factors influencing the satisfaction and effectiveness of e-learning courseware (Chiu, Hsu, Sun, Lin, \& Sun, 2005; Joo, Lim, \& Park, 2011; Liao \& Lu, 2008; Liptakova, 2009; H. C. Wang \& Chiu, 2011). That is positive development from 1997, when Guskey stated that most research reviews focused only on issues of quantity and neglect important quality issues. Khan (2005) stated that an e-learning system is meaningful to learners when it is easily accessible, well designed, learners-center, affordable, efficient, flexible and has facilitated learning environment.

Although the adoption of eLearning is on the rise and its popularity and overall investment on it is huge, the extant literature provides little insight into their beneficial consequences (Chen, 2010) and known results from eLearning are still regarded as not quite living up to its expectations (Au, Sadiq, \& Li, 2009); even some major concerns in its effectiveness and appropriateness have been revealed in various studies (Au et al., 2009). Many of the eLearning systems developed today were merely the automation of the process and management of teaching and delivering of courses with the advantages of eliminating the time and space barrier. The value towards better learning outcomes is still an area of study, although some researchers have recognized the issues and provided innovative solutions to solve some related problems (Au et al., 2009). An expectable e-learning versus traditional classroom learning development has resulted in blended learning.

Blended learning (b-learning) has formed as an answer to benefit, effectiveness and efficiency uncertainty of pure form of e-learning. It is referred to as distributed, hybrid, flexible, or multimodal learning (Duhaney, 2004; Gibson, 2006 in Kakkar, 2008) and is described as the combination of classroom instruction with self-paced online materials (Cennamo \& Kalk, 2004 in Kakkar, 2008). Blended learning mixes various event-based activities, including face-to-face classrooms, live e-learning, and self-paced learning. There is often a mix of traditional instructor-led training, synchronous online conferencing or training, asynchronous self-paced study. Blended learning appears to provide strong support for instructors looking to create learning settings based on strong learner-centered modes of delivery (Oliver, Reeves, \& Herrington, 2006). The blend often depends on the level of face-to-face communication that can be provided for students (Kakkar, 2008). Online distance courses (e-learning) are based on the compromise 
of the student with his/her learning process and are centered in the intensive use of online courses, while blended learning or mixed courses mainly use videoconferences and attending classes where the responsibility rests on both the professor and the student (Rivero-Villar, Murillo, Oseguera, \& Hidalgo, 2010).

\section{OBJECTIVES AND METHODOLOGY}

The research aim of the article was to analyze employees' assessment of the current system of education and training in the Slovak company whose purpose of business is selling the consumer goods. The company's management has implemented e-learning courses into its training program and subsequently expected training costs reduction accompanied by standard or better effects resulting from employees' practice. In this paper aspects of business training/learning system (compounded from several traditional courses and e-learning courses) will be analyzed while focusing on comparing the perceived quality, effectiveness and efficiency of e-learning and traditional way of training employees. Within the analysis of three sub-goals research will focus on 1. exploring manifested subjective employee's preference of one of two provided ways of business educating/training in the organization, 2. analysis how employees subjectively perceive quality, effectiveness and efficiency and benefits of two ways of corporate training conducted as either a conventional classroom training or e-learning and 3. comparing manifested preference of one of styles of training with learning style preference estimation derived from assessment of perceived quality, effectiveness and efficiency and benefits of two styles of learning supposing that the better evaluated aspects of a style of learning the higher is preference of such style of learning.

The analysis started with survey of attitudes of respondents towards two means of learning, conventional (traditional, face-to-face or classroom) and e-learning was conducted. We examined what benefits and negatives were perceived by workers being trained within the traditional educational process and within the e-learning training process. We were interested which way of learning was perceived more helpful for using acquired knowledge in carrying out their working activities. Presented survey results give information for decisions about the future direction of development of in-house training in the company under consideration.

Data was obtained by a questionnaire survey which took place from February to March 2013. Questionnaires were sent electronically using the Google Form application. They were distributed among employees - shop assistants of the particular company. All 150 sales persons were addressed and the questionnaire was completed by 119 respondents who had attended several courses of both types. Previous experience with e-learning or level of computer literacy was not examined. The questionnaire return rate was then 79,33\%. All respondents were women. More than half of them were 21 to 30 years old, $12,6 \%$ of them were younger than $21 ; 22,7 \%$ women were $31-40$ years old, $7,6 \%$ of them were $41-50$ years old and the size of category of shop assistants older than 50 was $5 \%$ of all respondents. The youngest women were mostly seasonal workers with the lowest attained education. One third of shop assistants attained first or second stage of higher education. Graduation of high school was not attained in 14,28\% of employees. 
Women came from places with different number of inhabitants, $30 \%$ of them came from small villages up to 500 inhabitants, another $29 \%$ from the towns over 50000 inhabitants and the remaining ratio of women came from larger villages or smaller towns.

Filling in the questionnaire was voluntary and anonymous. The questionnaire was characterized by pairwise questions relating to both forms of learning (e-learning and classroom learning), on the basis of which it would be possible to identify the strengths and weaknesses of both forms of training and draw conclusions leading to optimization of the training system.

To evaluate the preference derived from the quality, effectiveness and efficiency and benefits, assessment of two styles of learning, a Likert scale with set of four pairwise questions using Likert-type scales with reversed polarity $(1=$ strongly agree (positive evaluation); 5 = strongly disagree (negative evaluation) was incorporated into the questionnaire. Questions were intended to estimate respondents' inclination towards one or another style of learning through assessment of four aspects of training and to help identify strengths and weaknesses of these learning forms. The four pairwise Likert items were a priori specified according to expert decision of company's management representatives responsible for business training: 1. Quality and availability of studying materials, 2. Clarity and sufficiency of instructions, 3. Perceived learning/training effectiveness and efficiency and 4. Ability and possibility to apply knowledge acquired through both style of training in the employees' work.

Reliability of the scale assessed by Cronbach's alpha gives the acceptable result of $0,79(0,78$ for set of four questions underlying the e-learning concept and 0,77 for the set of another four questions underlying the traditional learning concept) since it is over recommended reliability coefficient of 0,70 (Croasmun \& Ostrom, 2011). The four pairwise Likert items consider evaluating from two points of view - e-learning and classroom of the four pairwise questions specified above.

While a high value for Cronbach's alpha indicates good internal consistency of the items in the scale, it does not mean that the scale is unidimensional (Gliem \& Gliem, 2003). Exploratory factor analysis research techniques were used to assess the validity and determine the dimensionality of the survey's scale. According to Thompson (2004) cited by Gliem and Gliem (2003), firstly, factor analysis reduces a large number of variables into a smaller set of variables (also referred to as factors), secondly, it establishes underlying dimensions between measured variables and latent constructs, thereby allowing the formation and refinement of theory and thirdly, it provides construct validity evidence of scales. Exploratory factor analysis is often considered to be more appropriate than confirmatory analysis in the early stages of scale development because confirmatory factor analysis does not show how well the items load on the other possible nonhypothesized factors (Hurley et al., 1997).

Number of collected data for factor analysis is sufficient for factor analysis to be suitable according to rule of thumb with smallest suggested sample size 50 cases (Williams, Brown, \& Onsman, 2012), Kaiser-Meyer-Olkin Measure of Sampling Adequacy (=0,774; minimum 0,5) and significant Bartlett's Test of Sphericity $\left(\chi^{2}=285,5\right.$; d.f. $=28$, p-value $\left.<0,000\right)$ (Joseph F Hair Jr, Anderson, \& Tatham, 1986; Tabachnick, Fidell, \& Osterlind, 2001). 
Ordinal type of data excludes multinormality, so utilizing the most widely used method in factor analysis supposing the variables' multinormality is an improper procedure in this case. A principal axis factoring as a factor extraction method (Costello \& Osborne, 2011) on all Likert items in questionnaire was conducted.

An examination of the scree plot of eigenvalues revealed that the curve leveled off after the first two factors (with eigenvalues above 1). These two factors accounting for $61 \%$ of the survey's responses variation were retained. According to Hair et al. (1995) in Williams's work (2012), in the natural sciences, factors should be stopped when at least $95 \%$ of the variance is explained. In the humanities, the explained variance is commonly as low as 50-60\% (Pett, Lackey, \& Sullivan, 2003) so the acceptable amount of variance will be explained.

Subsequently oblique Promax rotation (which allows a relationship between factors (Williams et al., 2012) supposed due to pairwise survey's items) was conducted. Factor loadings generated by these analyses are presented in Tab. 2 and Fig. 1. The pattern matrix holds the loadings. Each row of the pattern matrix is a regression equation where the standardized observed variable is expressed as a function of the factors. The loadings are the regression coefficients. The factor scores represent a linear combination of the observed variables weighted by eigenvectors. The observed variables in factor analysis are linear combinations of the underlying and unique factors. The structure matrix holds the correlations between the variables and the factors. All of the eight items loaded above 0,50 on one of the two factors. Hair Jr., Anderson and Tatham (1986) in Aladwani and Palvia's paper (2002) suggest that item loadings $>0,30$ are considered significant, $>0,40$ are more important, and $>0,50$ are considered very significant.

Tab. 2 - Factor loadings. Source: author.

\begin{tabular}{|c|c|c|c|c|}
\hline \multirow{2}{*}{ Item } & \multicolumn{2}{|c|}{ Pattern Matrix } & \multicolumn{2}{c|}{ Structure Matrix } \\
\cline { 2 - 5 } & \multicolumn{2}{|c|}{ Factor (E-learning) } & \multicolumn{2}{c|}{ Factor (Class) } \\
\cline { 2 - 5 } & 1 & 2 & 1 & 2 \\
\hline ele1 &, 703 &,- 067 &, 674 &, 233 \\
\hline ele2 &, 687 &, 150 &, 751 &, 444 \\
\hline ele3 &, 752 &,- 110 &, 705 &, 212 \\
\hline ele4 &, 601 &, 023 &, 611 &, 280 \\
\hline cla1 &,- 163 &, 646 &, 114 &, 577 \\
\hline cla2 &, 021 &, 686 &, 314 &, 695 \\
\hline cla3 &, 008 &, 844 &, 369 &, 847 \\
\hline cla4 &, 146 &, 546 &, 380 &, 608 \\
\hline
\end{tabular}

Notes: Extraction Method: Principal Axis Factoring. Rotation Method: Promax with Kaiser Normalization. a - Rotation converged in 3 iterations. 
The two rotated factors combined (subjectively named 1. quality of e-learning and 2. quality of traditional classroom learning) accounted for approximately $61 \%$ of total variance explained by initial eigenvalues.

Communalities in factor analysis indicate that each examined variable shares its variance with all other variables or how much of the variance in each of the original variables is explained by the extracted factors. All variables in the Tab. 3 share their variance after extraction of 0,354 to 0,718. Item communalities are considered "high" if they are all 0,8 or greater (Velicer \& Fava, 1998), but this is unlikely to occur in real data (Costello \& Osborne, 2011). More common magnitudes in the social sciences are low to moderate communalities of 0,40 to 0,70 . Probably other concurrently not examined factors can explain variables' variance or more variables then four per factor would increase the shared variance.

Tab. 3 - Communalities. Source: author.

\begin{tabular}{|c|c|c|}
\hline \multicolumn{3}{|c|}{ Communalities } \\
\hline & Initial & Extraction \\
\hline ele1 & 0,402 & 0,458 \\
\hline ele2 & 0,464 & 0,583 \\
\hline ele3 & 0,389 & 0,508 \\
\hline ele4 & 0,339 & 0,374 \\
\hline cla1 & 0,286 & 0,354 \\
\hline cla2 & 0,435 & 0,483 \\
\hline cla3 & 0,519 & 0,718 \\
\hline cla4 & 0,342 & 0,387 \\
\hline
\end{tabular}

Extraction Method: Principal Axis Factoring.

On the Fig. 1 the factor plot in rotated factor space shows the loadings for eight variables on the two factors. 1st factor "Quality of e-learning" has loaded all intended four variables with properties assessment of e-learning (and the 2nd factor "Quality of traditional classroom learning" has loaded all four variables with properties assessment of traditional classroom learning. We have two clusters of points with axes going through the middle of each cluster indicating good construct validity. 


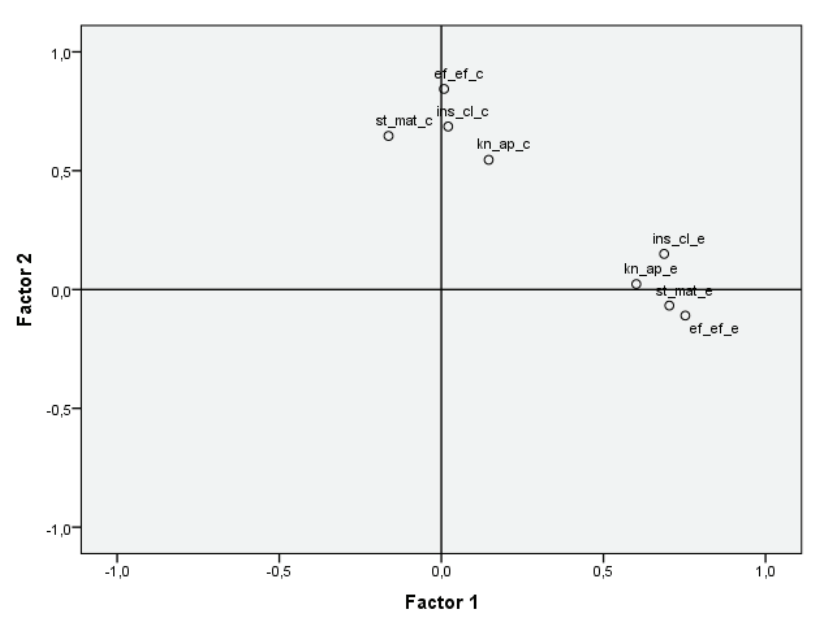

Factors and loaded variables:

Factor 1 : Classroom learning quality

1. Classroom studying materials quality and availability (st_mat_c=cla1)

2. Classroom instructions clarity (ins_cl_c=cla2)

3. Classroom effectivenes and efficiency (ef_ef_c $=$ cla3)

4. Classroom knowledge application $\left(\mathrm{kn} \_\right.$ap_c $=$cla4)

Factor 2 : E-learning quality

1. E-learning studying materials quality and availability (st_mat_e=ele1)

2. E-learning instructions clarity (ins_cl_e=ele2)

3. E-learning effectivenes and efficiency (ef_ef_e=ele3)

4. E-learning knowledge application (kn_ap_e=ele4)

Fig. 1 - Factor plot in rotated factor space. Source: author.

One control question of the survey is directly addressed the respondent's preference of one of the five forms of learning (1. only e-learning, 2. e-learning with elements of conventional classroom learning, 3. no preference of any form, 4. preference of conventional classroom learning with e-learning elements and 5. merely conventional classroom learning).

Remaining questions except of demographical questions examined respondents' opinions and suggestions about characteristics of the two types of learning.

To process and analyze data the program StatSoft Statistica, SPSS Statistics and Microsoft Excel was used. Since the character of collected data did not meet assumptions of normal distribution a non-parametric statistical methods were used to analyze data. Null and alternative hypotheses were developed and tested by different non-parametrical means. While investigating dependency of nominal and ordinal data a Pearson's Chi Square Test was used in association tables (more than 20 percent of theoretical frequencies amounted to less than 5 , therefore it was necessary to merge some of the cells) at the selected significance level of $\alpha=0,05$. Where dependency between the selected characteristics would be proven a null hypothesis would be rejected in favor of an alternative hypothesis at the selected level of significance of $\alpha=0,05$, the level of dependency would be tested by means of Cramer's V test. Dependencies of ordinal variables were tested by means of Spearman rank correlation coefficients. Where dependency between the selected ordinal variables was proven at the selected significance level of $\alpha=0,05$ a null hypothesis about independency was rejected in favor of an alternative hypothesis supporting assumption of relationship between variables. Hypotheses about equality of medians were tested by Sign/Wilcoxon pairwise test, Kruskal-Wallis ANOVA and Westenberg-Mood's Median test. Sign test provides a hypothesis test for median of sample. The null hypothesis specifies that median equals specified constant. Wilcoxon rank-sum test compares the medians of two groups. Significant difference means that ordinal variable depends on binary variable (group) so the medians of the two groups are not identical. Kruskal-Wallis test compares the medians of three or more groups of ordinal variable. It tests the null hypothesis that the different samples in the comparison are 
from distributions with the same median. Alternative hypothesis states that at least one median is different from the rest. Westenberg-Mood median test is more general although less powerful alternative to the Kruskal-Wallis test for testing if several independent samples of ordinal variable come from the same population. It tests whether two or more independent samples differ in their median values.

\section{RESULTS}

\subsection{Declared preference of one of five forms of training}

The primary survey question to be resolved was to specify a directly manifested employees' preference of one of the five forms of training. The respondents had a choice of pure forms of e-learning (assessment 1) or classical classroom learning (assessment 5), form with the dominant type of one type training with additional elements of the second type (assessments 2 and 4), or they could tick the option with the considered unimportance of the form of the training (assessment 3). This question was not a part of the Likert scale, nor summated construct. Distribution of the responses on the question is displayed on Fig. 2.

There is not a significant directly manifested preference of any pure form of learning. Respondents prefer the pure form of training, either e-learning or classroom training, only to a lesser extent $(19,32 \%)$, more frequently occurred hybrid form (38,66\% e-learning with classical elements and $34,45 \%$ classroom learning with e-learning elements). In summary, form of training with dominant e-learning or classroom form is only slightly different (statistically insignificantly) in favor of e-learning type in actual sample of shop assistants $(47,06 \%$ of shop assistants preferring pure e-learning or dominant e-learning with additional elements of conventional learning in comparison with $45,38 \%$ of shop assistant preferring only classroom learning or classroom learning with minor part of e-learning).

Choices for shop assistants' decisions for favorable form of learning may result from prior knowledge, experience and information technology skills, as well as the actual experience with training completed in the company in which they were employed. Possibly employees less skilled in information technology prefer conventional classroom learning. No examined demographical factor (age group, highest attained education or size of respondents' place of living) statistically significantly influenced the choice of the favorite way of learning ( $\mathrm{p}$ value of Pearson's Chi Square Test, Spearman rank correlation coefficient or Kruskal-Wallis ANOVA and WestenbergMood's Median Test was far above significance level of $\alpha=0,05$; thus null hypothesis about independence of variables could not by rejected). 


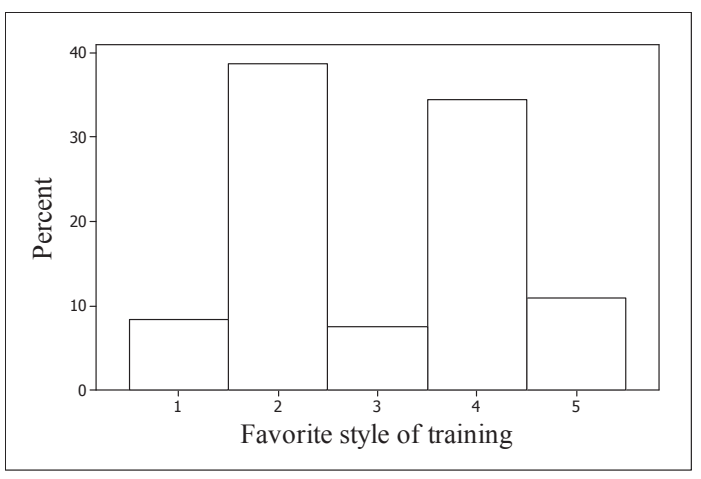

Legend for question of favorite style of training:

1. Merely e-learning training $(8,4 \%$ respondents)

2. E-learning with additional classroom training elements $(38,66 \%)$

3. Does not matter a training form $(7,56 \%)$

4. Classroom training with additional elearning elements $(34,45 \%)$

5. Merely classical classroom training $(10,92 \%)$

Fig. 2 - Frequencies of the preferences of a style of learning. Source: author.

Although from the survey management of the company could not recognize and rely on its employee's average prioritized form of the training to efficiently and effectively educate and train employees using e-learning or traditional style of training, bellow there are several analytical views that can help in decision making regarding the corporate training.

\subsection{Pairwise analysis}

Next part of research focused on analysis of differences between individual pairwise assessments of four items: 1. studying material quality and availability, 2. clarity of instructions, 3. effectiveness and efficiency of particular style of training and 4. applicability of knowledge acquired through the particular style of training (Fig. 4). When evaluating studying materials, clarity of instructions, perceived effectiveness and efficiency scores were rated on average better (the lower number the better assessment) in case of training using e learning, only the question of the ability of applying knowledge at work acquired conventionally was on average evaluated better. Except of the comparison of the questions about study materials all differences were statistically insignificant although with the better average sample perception of the e-learning (except of the case of application of acquired knowledge where some negative valuation of e-learning influenced average perception towards worst rating although insignificant. In summary, except of studying material we still cannot reject the uniformity in the preferences of both forms of training.

On the basis of Westenberg-Mood's median test with $\mathrm{Z}=1,734$ and $\mathrm{p}$-value $=0,0830$ as well as Wilcoxon pairwise test with $Z=0,378$ and $\mathrm{p}$-value $=0,705$ we cannot reject null hypotheses about equality of medians of both samples of summated responses of four Likert items at the selected level of significance of $\alpha=0.05$ (Fig. 3).

Mean of the summated scores for questions about e-learning is also only insignificantly better than summated score for questions about classroom learning. Fig. 3b illustrates proximity of average ratings of e-learning and classroom learning. Equality of samples's means cannot be rejected at the significance level of $\alpha=0.05$. 
a

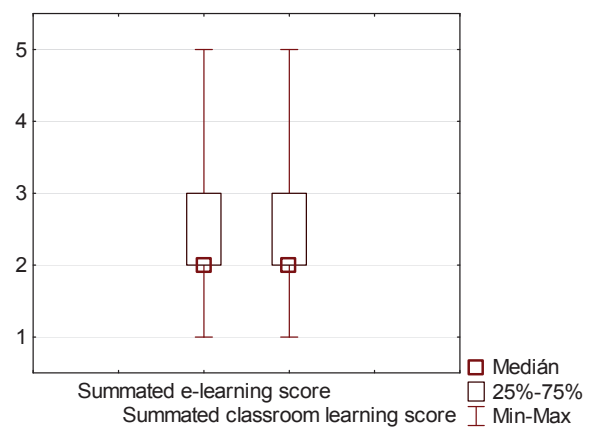

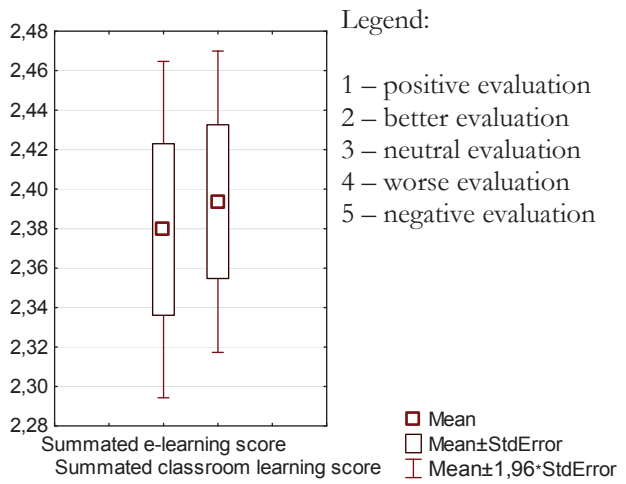

Fig. 3 - Distribution of summated ratings with median(a) and mean(b) rating of different aspects of both types of learning. Source: author.

At the actual stage of analysis, absolute preference of no way of learning can be proved and recommended. Following analysis of relationship between different factors of two ways of corporate training will clarify certain patterns.
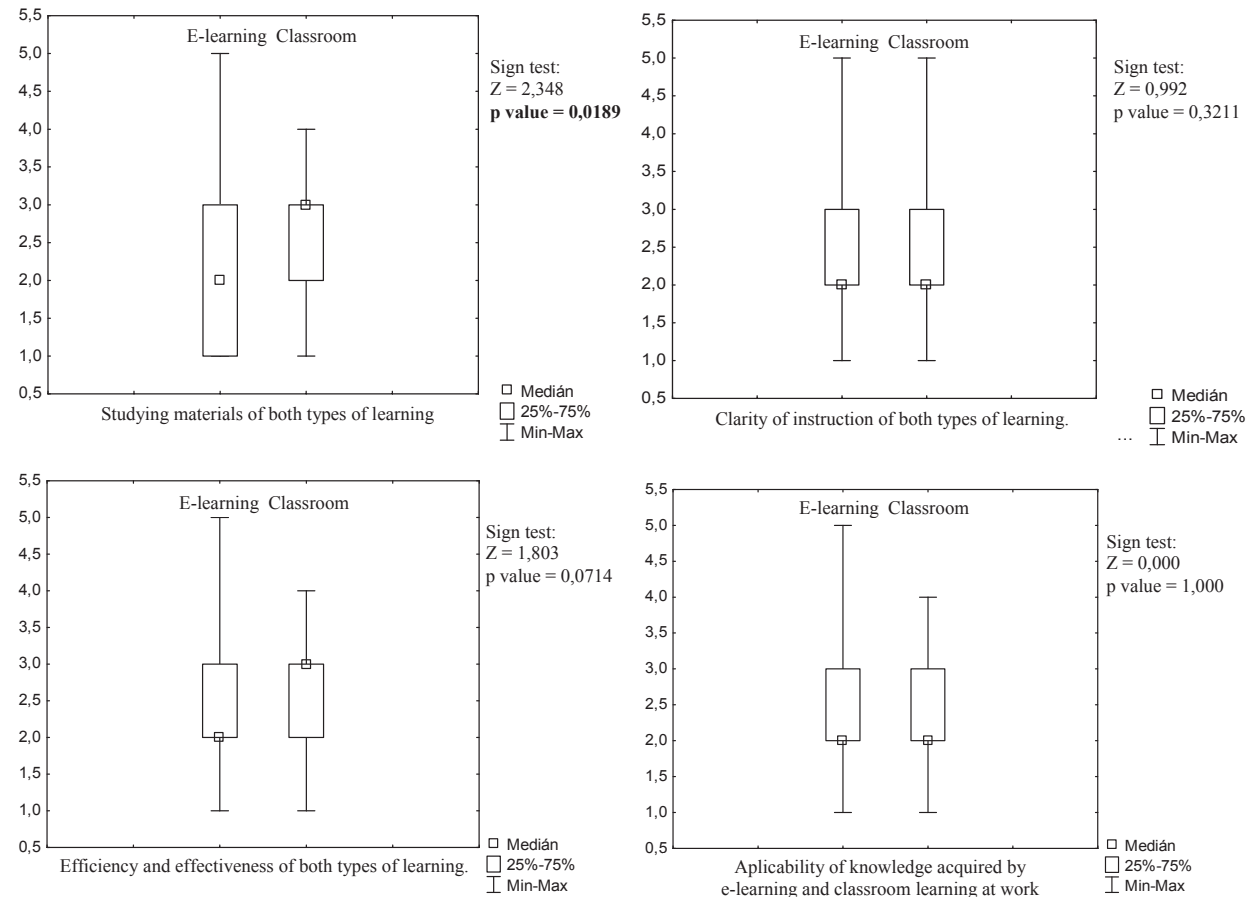

Legend:

1 - positive evaluation
2 - better evaluation

3 - neutral evaluation

4 - worse evaluation

5 - negative evaluation

Fig. 4 - Distribution of ratings of different aspects of both forms of learning. Source: author. 


\subsection{Test of two proportions}

Test of two proportion is the analysis, that can confirm or reject the hypothesis, that one of the type of learning is perceived better or we accept the conclusions of pairwise analysis in the chapter 4.2, that both types e-learning as well as conventional learning are perceived equally (except of studying material). In this analysis a proportion of positively (level 1 and 2 of summated Likert scale) evaluated characteristics of e-learning and conventional learning were compared. In case of e-learning evaluation there were four items, each evaluated by 119 respondents. 472 valid responses were obtained. 280 of them were strongly or somewhat positive (evaluation 1 and 2). Proportion of 59,32\% of all e-learning characteristics had positive evaluations. In case of conventional classroom learning evaluations there were also four Likert items, each evaluated by 119 respondents. 470 valid responses were obtained while evaluating the characteristics of conventional learning. 243 of conventional learning characteristics evaluations were strongly or somewhat positive, i.e. $51,70 \%$ positive evaluations of all conventional training's characteristics. At the level of significance of $\alpha=0.05$ the null hypotheses about equality of proportions was rejected ( $\mathrm{p}$ value $=0,0186)$. E learning thus has significantly more positive evaluations than conventional classroom learning.

At the other side, there is also statistically significant difference in two proportions of negative evaluating of e-learning and conventional classroom learning ( $\mathrm{p}$-value $=0,02) \cdot 10,59 \%$ of all assessments of e-learning aspects were negative while only 6,39\% of all assessments of conventional learning were negative. Those negatives could be solved to increase quality perception and effectiveness and efficiency of e-learning training program to maximize exploitation of benefits of training.

Although the proportion of positively evaluated responses is much higher than the proportion of negatives, an analysis of remaining survey questions regarding the opinions and suggestions of respondents should be conducted to eliminate weaknesses and negatives of the e-learning training program.

\subsection{Correlation analysis of the relationship between summated evaluation of e- learning and classroom learning characteristics.}

Nonparametrical Spearman rank correlation analysis of relationship between summated ratings of two types of learning confirms connection between summated ratings at the selected level of significance of $\alpha=0.05$. Spearman rank coefficient $\mathrm{Rs}=0,48$ indicates that those who perceive characteristics of one style of learning positively moderately incline to positive assessment of also the other style of learning. Graphical representation (Fig. 5) of the relationship of two variables and their histograms of distribution shows tendency of more often positive evaluation (bar 2 higher than bar 3 in the histogram) of the e-learning and tendency to be more often neutral while evaluating classroom learning (bar 3 higher than bar 2 in the histogram). 

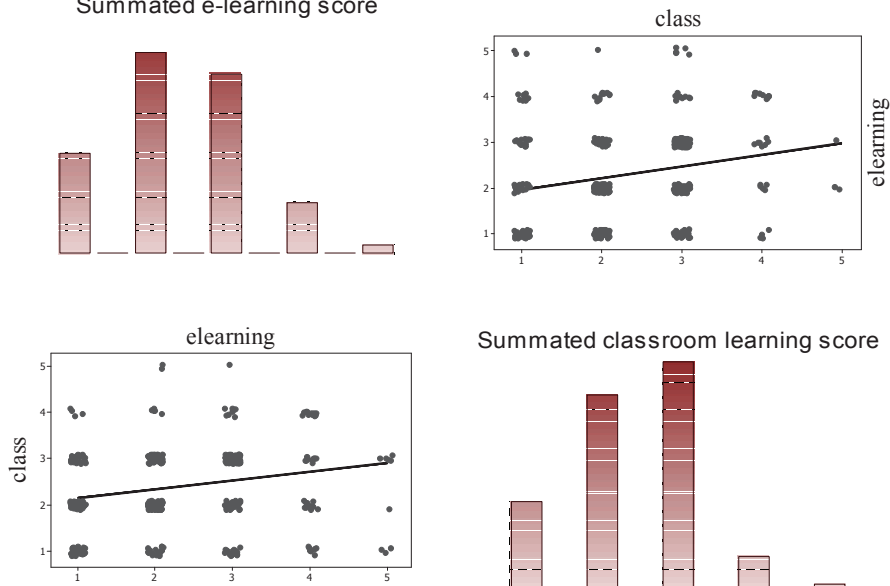

Summated classroom learning score

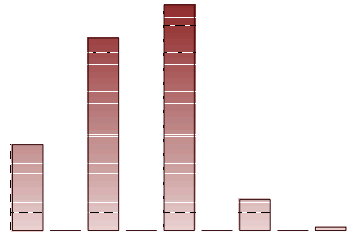

Fig. 5 - Analysis of the relationship between summated evaluation of e-learning and classroom learning characteristics Source: author.

\subsection{Analysis of the relationship between preference of the form of learning and four characteristics evaluation of two types of learning}

Four characteristics of types of learning (=Likert items with 1-pozitive and 5-negative assessment) are evaluated as it is noted in the methodology part of the third chapter. Their pairwise relationship as well as their connectivity to preferred form of learning (9th variable directly assessing the preference of the style of learning, not a Likert item) is analyzed. Bold formatted correlation coefficients are statistically significant at the level of significance of $\alpha=0.05$.

In Tab. 4 statistically significant Spearman correlation coefficients are observed between favorite form of training and studying materials evaluation of both learning types. Positive relationship is between favorite form choosing and positive evaluation of e-learning studying materials. The more respondents prefer e-learning type of learning the better she evaluates e-learning studying materials or in opposite view: the better e-learning material is perceived (and/or is in reality), the strongest average inclination towards pure form of e-learning training is. Since the strongest favoritism of merely classroom learning is coded as number 5 (see legend of the Fig. 1) there is negative statistically significant relationship between the form of learning and quality of conventional studying materials. The better is perceived the quality of conventional studying materials the higher average preference of classroom learning is.

Relationship between e-learning and classroom studying materials evaluation was not confirmed at the level of significance of $\alpha=0.05$. Those who positively evaluated one type of studying materials did not positively nor negatively assessed the other type of studying materials.

Tab. 5 confirms at the stated significance level of $\alpha=0.05$ the middle strong relationship only between clarity of instruction evaluation of the e-learning and classroom learning. Employees who understand to instructions within e-learning training they tend to understand also to instructions presented within classroom training or vice versa. Relationship between the prefer- 
ence of one of the forms of training and understandability of e-learning or classroom learning was not present.

Tab. 4 - Analysis of the relationship between preference of the form of learning and studying materials evaluation (bold formatted coefficients are statistically significant at $\alpha=0,05$ level). Source: author.

\begin{tabular}{|c|c|c|c|c|}
\hline \multirow{2}{*}{} & & \multicolumn{2}{|c|}{ Studying materials evaluation } \\
\cline { 2 - 5 } & $\begin{array}{c}\text { Favorite form of } \\
\text { training }\end{array}$ & E-learning & $\begin{array}{c}\text { Classroom } \\
\text { learning }\end{array}$ \\
\cline { 2 - 5 } & $\begin{array}{c}\text { Favorite form of } \\
\text { training }\end{array}$ & 1,000000 & $\mathbf{0 , 2 5 8 7 9 4}$ & $\mathbf{- 0 , 2 5 6 9 5 2}$ \\
\hline \multirow{2}{*}{$\begin{array}{c}\text { Studying materi- } \\
\text { als evaluation }\end{array}$} & $\begin{array}{c}\text { E-learning } \\
\text { Classroom } \\
\text { learning }\end{array}$ & $\mathbf{0 , 2 5 8 7 9 4}$ & 1,000000 & 0,145070 \\
\hline
\end{tabular}

The third analysis examines relationship between preference of the form of learning and perceived efficiency and effectiveness of e-learning or classroom learning (Tab. 6). A statistically significant week relationship can be found as a direct positive correlation between efficiency and effectiveness evaluation. Those who see efficient and effective e-learning perceive in this manner also classroom learning and those who do not consider one type of training efficient and effective she do not consider effective and efficient nor classroom learning. Of course the relationship is week, other factor influence effectiveness and efficiency perceiving. Preference only of an e-learning type of learning is statistically supported within the relationship with efficiency and effectiveness evaluation. Those who consider e-learning efficient and effective she tends to prefer this type of learning. In opposite, positively evaluated efficiency and effectiveness of classroom learning does not predict classroom learning preference according to results of Spearman rank correlation analysis.

Tab. 5 - Analysis of the relationship between preference of the form of learning and clarity of instructions evaluation (bold formatted coefficients are statistically significant at $\alpha=0,05$ level). Source: author.

\begin{tabular}{|c|c|c|c|c|}
\hline \multirow{2}{*}{} & & \multicolumn{2}{|c|}{ Clarity of instruction evaluation } \\
\cline { 2 - 5 } & $\begin{array}{c}\text { Favorite form of } \\
\text { training }\end{array}$ & E-learning & $\begin{array}{c}\text { Classroom } \\
\text { learning }\end{array}$ \\
\cline { 2 - 5 } & $\begin{array}{c}\text { Favorite form of } \\
\text { training }\end{array}$ & 1,000000 & 0,039559 & $-0,105806$ \\
\hline \multirow{2}{*}{$\begin{array}{c}\text { Clarity of } \\
\text { instruction } \\
\text { evaluation }\end{array}$} & $\begin{array}{c}\text { E-learning } \\
\text { Classroom } \\
\text { learning }\end{array}$ & 0,039559 & 1,000000 & $\mathbf{0 , 3 8 7 9 6 4}$ \\
\hline
\end{tabular}


Tab. 6 - Analysis of the relationship between preference of the form of learning and perceived efficiency and effectiveness of e-learning or classroom learning (bold formatted coefficients are statistically significant at $\alpha=0,05$ level). Source: author.

\begin{tabular}{|c|c|c|c|c|}
\hline \multirow{2}{*}{} & & & \multicolumn{2}{|c|}{$\begin{array}{r}\text { Efficiency and effectiveness } \\
\text { evaluation }\end{array}$} \\
\cline { 2 - 5 } & $\begin{array}{c}\text { Favourite form } \\
\text { of training }\end{array}$ & E-learning & $\begin{array}{c}\text { Classroom } \\
\text { learning }\end{array}$ \\
\cline { 2 - 5 } & $\begin{array}{c}\text { Favourite form } \\
\text { of training }\end{array}$ & 1,000000 & $\mathbf{0 , 2 8 6 9 4 4}$ & $-0,179250$ \\
\hline \multirow{2}{*}{$\begin{array}{c}\text { Efficiency and } \\
\text { effectiveness } \\
\text { evaluation }\end{array}$} & E-learning & $\mathbf{0 , 2 8 6 9 4 4}$ & 1,000000 & $\mathbf{0 , 2 6 9 4 4 9}$ \\
\cline { 2 - 5 } & $\begin{array}{c}\text { Classroom } \\
\text { learning }\end{array}$ & $-0,179250$ & $\mathbf{0 , 2 6 9 4 4 9}$ & 1,000000 \\
\hline
\end{tabular}

The last relationship investigation regards to analysis of the relationship between preference of the form of learning and level of e-learning or classroom learning knowledge application at work (Tab. 7). The level of usability of acquired knowledge in work statistically significantly relates on the level of significance of $\alpha=0.05$ with preference of the type of learning in both cases regarding e-learning as well as classroom learning. There is also a relationship between two variables of e-learning and classroom learning practical usability of knowledge acquired through e-learning and conventional way as well as mutual relationship between two ways of learning followed by level of knowledge usability in work. In average it is possible to predict (to some extent) favoritism of the e-learning training if respondent perceives practical usability of the knowledge acquired through internet. Similar situation is in opposite side. The larger confidence in usability of education acquired in classroom the higher probability for preference of conventional classroom learning. A weak statistically significant at the level of significance of $\alpha=0.05$ relationship between usability of knowledge acquired through e-learning and in classroom can be observed. Those who are able to apply their knowledge gained through internet at work, they are also able to use their knowledge gained in the classroom.

Tab. 7 - Analysis of the relationship between preference of the form of learning and level of elearning or classroom learning knowledge application at work (bold formatted coefficients are statistically significant at $\alpha=0,05$ level). Source: author.

\begin{tabular}{|c|c|c|c|c|}
\hline \multirow{2}{*}{} & & & \multicolumn{2}{|c|}{$\begin{array}{r}\text { Knowledge application at work } \\
\text { evaluation }\end{array}$} \\
\cline { 2 - 5 } & $\begin{array}{c}\text { Favorite form of } \\
\text { training }\end{array}$ & E-learning & $\begin{array}{c}\text { Classroom } \\
\text { learning }\end{array}$ \\
\cline { 2 - 5 } & $\begin{array}{c}\text { Favorite form of } \\
\text { training }\end{array}$ & 1,000000 & $\mathbf{0 , 2 5 8 4 1 2}$ & $\mathbf{- 0 , 2 0 0 4 0 3}$ \\
\hline $\begin{array}{c}\text { Knowledge ap- } \\
\text { plication at work } \\
\text { evaluation }\end{array}$ & $\begin{array}{c}\text { E-learning } \\
\text { Classroom } \\
\text { learning }\end{array}$ & $\mathbf{0 , 2 5 8 4 1 2}$ & 1,000000 & $\mathbf{0 , 2 7 2 8 6 2}$ \\
\hline
\end{tabular}


There are slightly more predictable and stable relationships between e-learning characteristics and e-learning preference on contrary with less clear relations or preference of classroom learning. Those who understand and use and learn exploiting e-learning system are in general more adaptable and can utilize any kind of knowledge in their work.

\section{DISCUSION AND CONCLUSIONS}

E-learning in corporate training is growing rapidly worldwide because of the pursuit of time and budget efficiency in course development and delivery. E-learning courses have become a part of education/training systems of many organizations not only of educational institutions but mainly of business companies optimizing their cost items. According to literature review there is not a clear evidence of e-learning's outright efficiency mainly in case we consider its overall effectiveness and after training benefits. Several comprehensive scientific suggestions stated in the first chapter about exploring factors influencing engagement in e-learning development and validated factor's structure assessing the training effectiveness or satisfaction were published. In this paper a simplified questionnaire tool presented in the paper with acceptable reliability and validity properties assessing the trainees' perceptions of quality, efficiency, effectiveness and benefits of traditional as well as e-learning style training has expressed itself as useful.

The purpose of this study was to ascertain which style of learning trainees prefer, how employees assess perceived attributes of learning in a company within an e-learning and traditional courses and how the evaluation of perceived attributes relates with manifested preference of a style of learning.

It was assumed that overall perceptions of learning were related to the aspects of quality of studying materials, clarity of instructions, effectiveness and efficiency of the learning and applicability of knowledge and skills acquired within both styles of learning what was validated through the factor analysis although with the lower degree of explained variability.

Only self-report measures of learning were used in the present study. It is possible that variables other than course quality factor may affect assessment of the perceived learning attributes as reported by employees, such as respondents' educational and working goals, past training experience, their cognitive skills, computer literacy, own motivation, economic issues, family or workplace circumstances and so on. A more extensive survey would must to be performed for those variables examination.

Data analysis revealed that there is not a significant directly manifested preference of any pure form of learning. employee's preference of merely e-learning or combined learning style with dominant e-learning was observed in comparison with the respondents number ratio manifested their preference of merely traditional learning or combined learning with dominant traditional style of learning. The most absolute prevalent style of learning was combined either with dominant e-learning approach or traditional features. It corresponds to increasing global occurrence and preference of blended learning pattern utilizing various learning strategies and delivery methods mixed to optimize the learning experience. 
Assessment of the traditional and e-learning courses did not show significant differences $(\alpha=$ $0,05)$ in average scores of individual attributes as well as summated scale (mean and median) for perceived characteristics (except of studying material assessment) of the two styles of learnings. In average both styles of learning are perceived equally. This finding resembles similar findings from performed studies noted in the first chapter that compared perceived properties and benefits of traditional classroom with those of e-learning education.

Detailed analysis of individual characteristics revealed that some quality failures were present concerning the traditional studying materials in comparison with e-learning studying materials. If two styles of learning are compared in one organization by the same trainees concurrently, the better perceived (assessed) learning style could be a benchmark marking difference between expectations of trainees which stands for the best average reached score of better assessed learning style's characteristic and actual score of the stagnant characteristic of the other learning style. Courses instructions clarity, effectiveness, efficiency and acquired knowledge applicability were assessed on average equally (equality could not be rejected at significance level of $\alpha=0,05$ ). It does not mean that there is not a space for improving it. Employees who did not assess the characteristic by the best possible score were aware of the deficiencies. Evolution over time could be monitored using the repeated assessments.

Statistically significant higher ratio of the positive evaluations of e-learnings' attributes ( 1 - strong positive and 2 - somewhat positive) (significance level of $\alpha=0,05$ ) may suggest that in the company e-learning would by better evaluated and therefor more preferable. On the other side there is also higher statistically significant ratio of number of negatively evaluated e-learning attributes what shifts the average evaluation to the level of average evaluation of traditional courses.

Spearman rank coefficient $\mathrm{R}_{\mathrm{s}}=0,48$ indicates that those who perceive characteristics of one style of learning positively moderately incline to positive evaluation also of the other style of learning. Probably other independent factors such as cognitive attributes, self-motivation, personality and others can involve in the attitude rendering. Similarly relationships of individual items and favorite form of training were explored with the conclusion that between assessment of a style of learning and stated preference of a style of learning is only a week statistically significant relationship (at the level of $\alpha=0,05$ ).

Statistical analysis in this study revealed that perceived quality, effectiveness, efficiency and benefits of two styles of learning are comparable individually as well as through the summated scale and also the preference of a learning style is not clear what is in accordance with worldwide studies and trends. Although several procedures to remedy negative aspects of one learning styles could be performed anytime to increase their potential, there would still remain important number of employees who do not prefer the other learning style regardless its quality and positive other aspects and those employees would not be able to acquire and utilize new knowledge and thus the learning performance would be decreased. This seems that blended learning style could have possibility at least partially to consolidate strengths of both styles of learning and eliminate quality, effectiveness, efficiency, knowledge application ability and other weaknesses to improve the corporate training/learning performance and trainees' satisfaction. 


\section{References}

1. Al-Furaydi, A. A. (2013). Measuring E-Learning Readiness among EFL Teachers in Intermediate Public Schools in Saudi Arabia. English Language Teaching, 6(7), 110-121.

2. Aladwani, A. M., \& Palvia, P. C. (2002). Developing and validating an instrument for measuring user-perceived web quality. Information \& Management, 39(6), 467-476. http:// dx.doi.org/10.1016/S0378-7206(01)00113-6

3. Allen, I. E., \& Seaman, J. (2008). Staying the course: Online education in the United States. Babson Survey Research Group: The Sloan Consortium.

4. Au, T. W., Sadiq, S., \& Li, X. (2009). Learning From Experience: Can e-Learning Technology be Used as a Vehicle? In. Salajan, F. (Ed.), 4th International Conference on e-Learning (pp. 32). Reading, UK: Academic Conferences Ltd.

5. Batte, M. T., Forster, D. L., \& Larson, D. W. (2003). An assessment of student acceptance and performance in distance education with two-way interactive compressed video. Review of Agricultural Economics, 25(2), 524-539. http://dx.doi.org/10.1111/1467-9353.00153

6. Bernard, R. M., Abrami, P. C., Lou, Y., Borokhovski, E., Wade, A., Wozney, L., \& Huang, B. (2004). How does distance education compare with classroom instruction? A metaanalysis of the empirical literature. Review of educational research, 74(3), 379-439. http://dx.doi. org/10.3102/00346543074003379

7. Berry, J. (2000). Corporate training - the e-learning center - Companies are using metrics to justify e-learning's impact on strategic business goals. InternetWeek, 836(November 6), 61-64.

8. Bhattacherjee, A. (2001). Understanding information systems continuance: an expectationconfirmation model. MIS quarterly, 25(3), 351-370. http://dx.doi.org/10.2307/3250921

9. Blake, C., Jane Whitney, G., \& Blackwell, C. W. (2003). Web-based training: What supervisors need to know. SuperVision, 64(12), 3-7.

10. Bucciarelli, E., Muratore, F., \& Odoardi, I. (2010). Consolidation processes of human capital in modern economic growth dynamics: an estimate based on the role of European corporate e-learning activities. In H. Keser, Z. Ozcinar \& S. Kanbul (Eds.), World Conference on Learning, Teaching and Administration Papers (Vol. 9). Amsterdam: Elsevier Science Bv.

11. Cennamo, K., \& Kalk, D. (2004). Real world instructional design. Recording for the Blind \& Dyslexic.

12. Cervená, K. (2011). Efektivnost'vzdelávania v podmienkach Slovenskej republiky. Paper presented at the Humanizácia vzdelávania na technických univerzitách: scientific papers proceeding. Bratislava.

13. Chen, H. J. (2010). Linking employees' e-learning system use to their overall job outcomes: An empirical study based on the IS success model. Computers \& Education, 55(4), 1628-1639. http://dx.doi.org/10.1016/j.compedu.2010.07.005

14. Chiu, C. M., Hsu, M. H., Sun, S. Y., Lin, T. C., \& Sun, P. C. (2005). Usability, quality, value and e-learning continuance decisions. Computers \& Education, 45(4), 399-416. http://dx.doi. org/10.1016/j.compedu.2004.06.001 
15. Clark, R. C., \& Mayer, R. E. (2008). E-learning and the science of instruction. USA: John Willey \& Sons.

16. Costello, A. B., \& Osborne, J. W. (2011). Best practices in exploratory factor analysis: four recommendations for getting the most from your analysis. Practical Assessment, Research \& Evaluation, 10(7), 1-9.

17. Croasmun, J. T., \& Ostrom, L. (2011). Using Likert-Type Scales in the Social Sciences. Journal of Adult Education, 40(1), 19-22.

18. Dongsong, Z., Zhao, J. L., Lina, Z., \& Nunamaker, J. J. F. (2004). Can e-learning replace classroom learning? Communications of the $A C M, 47(5), 75-79$. http://dx.doi.org/10.1145/986 213.986216

19. Duhaney, D. C. (2004). Blended learning in education, training, and development. Performance Improvement, 43(8), 35-38. http://dx.doi.org/10.1002/pfi.4140430810

20. Gibson, T. (2006). Blended learning: The best recipe. Training Journal, 36-38.

21. Gliem, J. A., \& Gliem, R. R. (2003). Calculating, interpreting, and reporting Cronbach's alpha reliability coefficient for Likert-type scales. In. Proceedings of Midwest Research to Practice Conference in Adult, Continuing, and Community Education (pp. 82-88). Columbus, Ohio.

22. Guskey, T. R. (1997). Research needs to link professional development and student learning. Journal of staff development, 18(2), 36-41.

23. Hair Jr, J. F., Anderson, R. E., \& Tatham, R. L. (1986). Multivariate data analysis with readings. Macmillan Publishing Co., Inc.

24. Hair Jr, J. F., Anderson, R. E., Tatham, R. L., \& Black, W.C. (1995), Multivariate data analysis with readings. New Jersy: Prentice Hall.

25. Hairston, N. R. (2007). Employees' attitude toward e-learning: Implications for policy in industry environments. Dissertation, University of Arkansas, Ann Arbor.

26. Hiltz, S. R., \& Wellman, B. (1997). Asynchronous learning networks as a virtual classroom. Communications of the ACM, 40(9), 44-49. http://dx.doi.org/10.1145/260750.260764

27. Ho, C. L., \& Dzeng, R. J. (2010). Construction safety training via e-Learning: Learning effectiveness and user satisfaction. Computers \& Education, 55(2), 858-867. http://dx.doi. org/10.1016/j.compedu.2010.03.017

28. Hurley, A. E., Scandura, T. A., Schriesheim, C. A., Brannick, M. T., Seers, A., Vandenberg, R. J., \& Williams, L. J. (1997). Exploratory and confirmatory factor analysis: guidelines, issues, and alternatives. Journal of Organizational Behavior, 18(6), 667-683. http://dx.doi. org/10.1002/(SICI)1099-1379(199711)18:6<667::AID-JOB874>3.0.CO;2-T

29. Hussin, H., Bunyarit, F., \& Hussein, R. (2009). Instructional design and e-learning. Campus - Wide Information Systems, 26(1), 4-19. http://dx.doi.org/10.1108/10650740910921537

30. Joo, Y. J., Lim, K. Y., \& Park, S. Y. (2011). Investigating the structural relationships among organisational support, learning flow, learners' satisfaction and learning transfer in corporate e-learning. British Journal of Educational Technology, 42(6), 973-984. http://dx.doi. $\operatorname{org} / 10.1111 / \mathrm{j} .1467-8535.2010 .01116 . x$ 
31. Kakkar, M. (2008). A synthesis of good design practices for stand alone "Global e-learning" for global organisations. Dissertation, Concordia University (Canada), Ann Arbor.

32. Khan, B. H. (2005). Managing e-learning strategies: Design, delivery, implementation and evaluation. Hershey, PA: Information Science Publishing. http://dx.doi.org/10.4018/978-1-59140-634-1

33. Klimplová, L. (2012). Employers' View on Problems Related to Workforce Skills and Qualification. Journal of Competitiveness, 4(4), 50-66. http://dx.doi.org/10.7441/joc.2012.04.04

34. Liao, H. L., \& Lu, H. P. (2008). The role of experience and innovation characteristics in the adoption and continued use of e-learning websites. Computers \& Education, 51(4), 1405-1416. http://dx.doi.org/10.1016/j.compedu.2007.11.006

35. Lim, D. H. (2002). Perceived differences between classroom and distance education: Seeking instructional strategies for learning applications. International Journal of Educational Technology, 3(1), 20-32.

36. Liptakova, E. (2009). Faktory ovplyvňujúce úspešnost' e-learningu. Disputationes Scientificae: Universitatis Catholicae in Ružomberok, 9(4), 47-57.

37. Luor, T. Y., Hu, C. Y., \& Lu, H. P. (2009). 'Mind the gap': An empirical study of the gap between intention and actual usage of corporate e-learning programmes in the financial industry. British Journal of Educational Technology, 40(4), 713-732. http://dx.doi.org/10.1111/ j.1467-8535.2008.00853.x

38. Mansour, M. (2009). Employees Perception and Satisfaction about e-Learning in the Workplace. Reading: Academic Conferences Ltd.

39. Mayes, T., \& De Freitas, S. (2006). Review of e-learning theories, frameworks and models. JISC e-Learning Models Desk Study. Retrieved from: http://www.jisc.ac.uk/uploaded_ documents/Stage $\% 202 \% 20$ Learning\%20Models\%20\%28Version\%201\%29.pdf

40. Midkiff, S. F., \& DaSilva, L. A. (2000). Leveraging the web for synchronous versus asynchronous distance learning. Paper presented at the International Conference on Engineering Education. Taipei, Tainan (Taiwan).

41. Mihartescu, A. A., Negrut, M. L., \& Mazilescu, C. A. (2010). From traditional learning to elearning. Iasi: Univ Tech Gheorghe Asachi Iasi.

42. Morse, K. (2003). Does one size fit all? Exploring asynchronous learning in a multicultural environment. Journal of Asynchronous Learning Networks, 7(1), 37-55.

43. Mouzakitis, G. S. (2009). E-Learning: The six important "Wh ... ?”. In H. Uzunboylu \& N. Cavus (Eds.), World Conference on Educational Sciences - New Trends and Issues in Educational Sciences (Vol. 1, pp. 2595-2599). Amsterdam: Elsevier Science Bv.

44. Nakayama, M. K., da Silva Schroeder, C., Pilla, B. S., Haro, D. G., \& Binotto, E. (2005). Virtual corporate training systems - Defining criteria and indicators for evaluation. In T. VanWeert \& A. Tatnall (Eds.), Information and Communication Technologies and Real-Life Learning: New Education For The Knowledge Society (Vol. 182, pp. 13-20). New York: Springer. http:// dx.doi.org/10.1007/0-387-25997-X_2

45. Olafsen, R. N., \& Cetindamar, D. (2005). E-learning in a competitive firm setting. Innovations in Education and Teaching International, 42(4), 325-335. http://dx.doi.org/10.1080/14 703290500062581 
46. Oliver, R., Reeves, T. C., \& Herrington, J. A. (2006). Creating authentic learning environments through blended-learning approaches. In C. Bonk \& C. R. Graham (Eds.), Handbook of blended learning: Global perspectives, local designs (pp. 502-515). San Francisco, CA: Pfeiffer Publishing.

47. Omwenga, E., \& Rodrigues, A. (2006). Towards an education evaluation framework: synchronous and asynchronous e-learning cases. Journal of the Research Center for Educational Technology, 2(1), 46-59.

48. Ozturan, M., \& Kutlu, B. (2010). Employee satisfaction of corporate e-training programs. In H. Uzunboylu (Ed.), Innovation and Creativity in Education (Vol. 2, pp. 5561-5565). Amsterdam: Elsevier Science Bv.

49. Pantazis, C. (2001). Executive summary: A vision of E-learning for America's workforce. Report of the Commission on Technology and Adult Learning, ASTD.

50. Pett, M. A., Lackey, N. R., \& Sullivan, J. J. (2003). Making sense of factor analysis: The use of factor analysis for instrument development in bealth care research. California: Sage.

51. Pilla, B. S., Nakayama, M. K., \& Nicholson, P. (2006). Characterizing e-learning practices in companies - an exploratory research in Australia. In D. Kumar \& J. Turner (Eds.), Education for the 21st Century - Impact of ICT and Digital Resources (Vol. 210, pp. 145-154). New York: Springer. http://dx.doi.org/10.1007/978-0-387-34731-8_16

52. Rivero-Villar, M. J., Murillo, L. M. R., Oseguera, S. C., \& Hidalgo, T. L. D. (2010). Effectiveness comparison between online distance courses (e-learning) and mixed attending and online courses (b-learning) to develop competencies. Valenica: Iated-Int Assoc Technology Education a\& Development.

53. Russell, T. L. (1999) The No Significant Difference Phenomenon. Raleigh: NC, North Carolina State.

54. Schoenfeld-Tacher, R., McConnell, S., \& Graham, M. (2001). Do no harm - A comparison of the effects of on-line vs. traditional delivery media on a science course. Journal of Science Education and Technology, 10(3), 257-265. http://dx.doi.org/10.1023/A:1016690600795

55. Shea, R. H. (2002). E-Learning Today; As an industry shakes out, the survivors offer nofrills education for grown-ups. U.S. News \& World Report, 133, 54-56.

56. Suanpang, P., Petocz, P., \& Kalceff, W. (2004). Student attitudes to learning business statistics: Comparison of online and traditional methods. Educational Technology \& Society, 7(3), 9-20.

57. Tabachnick, B. G., Fidell, L. S., \& Osterlind, S. J. (2001). Using multivariate statistics.

58. Thompson, B. (2004). Exploratory and confirmatory factor analysis: Understanding concepts and applications. Washington, DC, US: American Psychological Association. http://dx.doi. org $/ 10.1037 / 10694-000$

59. Vargas, N., \& Tian, X. (2013). E-Learning: Much More than a Matter of Technology. International Journal of e-Education, e-Business, e-Management and e-Learning, 3(3), 277. http:// dx.doi.org/10.7763/IJEEEE.2013.V3.240

60. Velicer, W. F., \& Fava, J. L. (1998). Affects of variable and subject sampling on factor pattern recovery. Psychological methods, 3(2), 231-251. http://dx.doi.org/10.1037/1082989X.3.2.231 
61. Wang, H. C., \& Chiu, Y. F. (2011). Assessing e-learning 2.0 system success. Computers \& Education, 57(2), 1790-1800. http://dx.doi.org/10.1016/j.compedu.2011.03.009

62. Wang, Y.-S., Wang, H.-Y., \& Shee, D. Y. (2007). Measuring e-learning systems success in an organizational context: Scale development and validation. Computers in Human Behavior, 23(4), 1792-1808. http://dx.doi.org/10.1016/j.chb.2005.10.006

63. Wild, R. H., Griggs, K. A., \& Downing, T. (2002). A framework for e-learning as a tool for knowledge management. Industrial Management \& Data Systems, 102(7), 371-380. http:// dx.doi.org/10.1108/02635570210439463

64. Williams, B., Brown, T., \& Onsman, A. (2012). Exploratory factor analysis: A five-step guide for novices. Journal of Emergency Primary Health Care, 8(3), 1-13.

65. Yeung, P., \& Jordan, E. (2006). Understanding the continued usage of business e-learning courses in HK corporations. In D. Kumar \& J. Turner (Eds.), Education for the 21st Century Impact of ICT and Digital Resources (Vol. 210, pp. 245-254). New York: Springer. http://dx.doi. org $/ 10.1007 / 978-0-387-34731-8 \_26$

66. Šimová, K., Závadský, C., \& Andrejkovič, M. (2008). Manažérskee prístupy a vplyv inovácií na ich vývoj. Paper presented at the Ekonomika, financie a manažment podniku II.: vedecká konferencia doktorandov Fakulty podnikového manažmentu, Bratislava.

\section{Contact information}

Ing. Monika Conková, PhD.

University of Economics in Bratislava, Faculty of Business Economy in Kosice

Tajouskébo 13, 04130 Košice, Slovak Republic

Email:monika.conkova@euke.sk 